\title{
IAMJ
}

INTERNATIONAL

AYURVEDIC

MEDICAL JOURNAL

ISSN: 23205091

Impact Factor: 5.344

\section{TO EVALUATE THE EFFECT OF JALAUKAVCHARANA IN MANAGEMENT OF MUKHDUSHIKA W.S.R TO ACNE VULGARIS: A CASE STUDY}

\author{
Punita Sharma ${ }^{1}$, Chhaju Ram Yadav ${ }^{2}$, Sarika Yadav ${ }^{3}$ \\ ${ }^{1} \mathrm{PG}$ Scholar, ${ }^{2}$ Associate Professor, ${ }^{3}$ Lecturer, \\ PG Department of Sharir Kriya, National Institute of Ayurveda, Jaipur, Rajasthan-302002, India
}

Email: punitadadhich93@gmail.com

\section{https://doi.org/ 10.46607/iamjp04042020}

(Published online: May 2020)

Open Access

(C) International Ayurvedic Medical Journal, India 2020

Article Received: 07/04/2020 - Peer Reviewed: 07/05/2020 - Accepted for Publication: 07/05/2020

\section{Check for updates}

\begin{abstract}
In modern era, Acne is the most common skin disease facing mankind, it afflicts $80 \%$ of adolescent in population. In modern dermatology, a similar type of skin disorder named Acne vulgaris or Acne is found to have parity with the disease Mukhdushika or Yuvanpidika mentioned in Ayurvedic text. This problem is aggravated are increasing day by day due to excessive stress, hormonal imbalance, salty food, junk food and modern lifestyle. So, purpose of the study is to evaluate the application of Jalouka and herbo-mineral compound in Mukhdushika w.s.r to acne vulgaris. A 21 years old patient came in OPD (skin care unit) at NIA, Jaipur with the complaints of acne (nodular) for 1 year with pain, tenderness, burning, itching, discharge and discolouration diagnosed as Mukhdushika. Patient was administrated a herbomineral compound along with Jalaukavacharana with the follow up of 7 days. The main drugs of Herbomineral compounds were Manjishtha, Rasmanikya etc. all these drugs have the properties of Kushthaghna, Raktaprasadaka, Varnaprasadaka, Yakrit Uttejaka etc. Jalouka therapy was also given along with every week upto 12 weeks. The result of the combined therapy was encouraging without any side effects.
\end{abstract}

Keyword- Mukhdushika, Jalouka, Herbo mineral compounds, Acne vulgaris 
Skin is largest organ of our body. Human skin reflects the health and personality of a person. Any skin disease affects the person's psychological status and may disturb social life. The patient may feel some kind of inferiority complex, because it gives hilarious look. The most common skin disease in the youth is Acne. These occur in youngsters and in form of boil or Pidika. This disease vitiates the facial appearance hence known as Mukhdushika. The disease comes under the Ksudra Roga. According to Acharya Sushruta ${ }^{l}$. The eruptions like Shalmali thorn, on the face during adolescence caused by vitiated Kapha, Vata and Rakta are known as Mukhadusika. Acharya Charaka has stated involvement of vitiated Rakta in pathophysiology of Pidika. Acharya Vagbhatta has mentioned the role of $M e d a^{2}$ in the pathology of Mukhadusika which resembles with modern theory of sebum involvement in the pathogenesis of acne. As per modern science the sign and symptoms of Mukhdushika can be co-related with acne vulgaris. Acne vulgaris is a disorder of pilosebaceous gland mainly affect the youth population, which manifest as comedones may be open or closed, papules, nodules, postules heals with scar. It is formed due to blockage of pilosebaceous gland by keratinous plug. Modern medications for acne include topical therapies, antimicrobials, hormones, surgery, U-V Irradiation, Intra lesions injections etc. having their own limitations. While Antibiotic resistance in acne patients to doxycycline, azithromycin, clindamycin, tetracycline is also an emerging problem. But none of the modern treatment permanently cures the disease and only effective for short time with very high rate of relapse.

Need Of The Hour: A person suffers from Mukhadushika especially at the stage of adolescent. In this period of life young adults strives hard to look beautiful and attractive but Mukhadushika is a prime barrier to achieve this goal. Other pathies provide less relief and more side effects such as corticosteroids, Laser therapy, local thermal facial packs etc. Ayurveda having the potential to cure Mukhadushika with its herbomineral compound and procedures. Jalaukavacharana was described by Acharya Sushruta, it plays an important role in purification of blood and also enhance blood flow in the facial part. However, herbomineral compound along with Jalaukavacharana having very least side effects and it is cost effective remedy for the treatment of Mukhadushika (acne vulgaris).

\section{Aim \& Objectives}

1. To study the concept of Mukhdushika w.r.s. acne vulgaris.

2. To study the efficacy of Jaloukavcharan along with herbomineral w.s.r. to Mukhdushika.

\section{Material and Methods}

\section{Case Report}

21-year-old female patient visited in the OPD of Skin Care Unit, Sharir Kriya department, NIA Jaipur, with classical sign and symptoms of Mukhdushika.

\section{Chief Complaints}

- Acne over face (Pidika)

- Burning sensation over face (Daha)

- Itching over face (Kandu)

- Discolouration of skin (Vaivarnya) etc.

History of Present Illness: The patient had above complaints since last one and half year. In this period, she experienced small pustules over her both cheeks. Also, she had itching and burning sensation over these areas. The patient tried various allopathic local as well as systemic drugs but none could prevent the relapse of acne. So, she came to the OPD for Ayurvedic treatment. Past History: Not any relevant history found.

\section{Personal History}

\begin{tabular}{|c|c|c|c|c|c|}
\hline Name & - & XYZ & B.P. & - & $110 / 70 \mathrm{~mm}$ of $\mathrm{Hg}$ \\
\hline Bala & - & Madhyam & Sex & - & Female \\
\hline Prakruti & - & Pitta-Vata & Bowel Habit & - & Irregular \\
\hline Age & - & 21 years & Occupation & - & Student \\
\hline Sleep & - & Inadequate & Appetite & - & Normal \\
\hline
\end{tabular}




\section{Ashtavidh Pariksha}

Nadi (Pulse)- 76 per min

Mala (Stool)- Constipation

Mutra (Urine)- Samyaka

Jivha (Tongue)- Saam

\author{
Shabda (Speech)- Clear \\ Sparsh (Touch)- Clear \\ Druk (Eyes)- Prakrut \\ Aakruti (Built)- Madhyam
}

Material with Daily treatment \& prognosis -

Patient was given 7 sittings of Jalaukavacharana on a 7 days interval along with herbomineral drugs.

\begin{tabular}{|c|c|c|c|c|c|}
\hline S.No & Dravya & \multicolumn{2}{|l|}{ Dose } & Duration & Anupaan \\
\hline \multirow[t]{6}{*}{1.} & Manjishthadi Churna & $3 \mathrm{gm}$ & \multirow{6}{*}{$\begin{array}{l}1 \text { pack BD twice } \\
\text { a day empty } \\
\text { stomach }\end{array}$} & \multirow[t]{6}{*}{ For 7 days } & \multirow[t]{6}{*}{ With lukewarm water } \\
\hline & Rasmanikya & $250 \mathrm{mg}$ & & & \\
\hline & Shuddha Gandhak & $1 \mathrm{gm}$ & & & \\
\hline & Nimbadi Churna & $1 \mathrm{gm}$ & & & \\
\hline & Godanti Bhasam & $250 \mathrm{mg}$ & & & \\
\hline & Kanchnar Guggulu & $2 \times 2$ & & & \\
\hline 2. & Kaishor Guggulu & \multicolumn{2}{|l|}{$2 \times 2$} & For 7 days & With lukewarm water \\
\hline 3. & $\begin{array}{l}\text { Aamdoshantak Vati } \\
\text { (Kutaj, Twak, Shunthi, Haritaki, } \\
\text { Chitrak, Pippali, Bilva-Gooda) }\end{array}$ & \multicolumn{2}{|l|}{$2 \times 2$} & For 7 days & With lukewarm water \\
\hline
\end{tabular}

\begin{tabular}{|c|c|c|c|c|c|}
\hline \multirow[t]{2}{*}{ Visit } & \multirow[t]{2}{*}{ Treatment } & \multicolumn{4}{|c|}{ Relief in symptoms } \\
\hline & & $\begin{array}{l}\text { Acne over } \\
\text { face (Pidika) }\end{array}$ & $\begin{array}{l}\text { Burning sensation } \\
\text { over face }(D a h a)\end{array}$ & $\begin{array}{l}\text { Itching over } \\
\text { face }(\text { Kandu })\end{array}$ & $\begin{array}{l}\text { Discolouration of skin } \\
\text { (Vaivarnya) }\end{array}$ \\
\hline $2^{\text {nd }}$ & $\begin{array}{l}\text { All the above treatment as it is }+ \\
2^{\text {nd }} \text { sitting of Jalaukacharan }\end{array}$ & + & ++ & ++ & + \\
\hline $3^{\text {rd }}$ & $\begin{array}{l}\text { All the above treatment as it is } \\
+3^{\text {rd }} \text { sitting of Jalaukacharan }\end{array}$ & ++ & +++ & ++ & + \\
\hline $4^{\text {th }}$ & $\begin{array}{l}\text { All the above treatment as it is } \\
+4^{\text {th }} \text { sitting of Jalaukacharan }\end{array}$ & +++ & +++ & +++ & ++ \\
\hline $5^{\text {th }}$ & $\begin{array}{l}\text { All the above treatment as it is } \\
+5^{\text {th }} \text { sitting of Jalaukacharan }\end{array}$ & Almost cured & Almost cured & Almost cured & Almost cured \\
\hline $6^{\text {th }}$ & $\begin{array}{l}\text { All the above treatment as it is } \\
+6^{\text {th }} \text { sitting of Jalaukacharan }\end{array}$ & Almost cured & Cured & Cured & Almost cured \\
\hline $7^{\text {th }}$ & $\begin{array}{l}\text { All the above treatment as it is } \\
+7^{\text {th }} \text { sitting of Jalaukacharan }\end{array}$ & Cured & Cured & Cured & Cured \\
\hline
\end{tabular}

\section{Hetu of Mukhdushika}

Ahara:-Ahara is one of Trayopstmbha and its considered as one of the chief responsible factors of any disease. Acharya Charaka has described that taking of Viruddha Ahara (Incompatible or antagonistic diet) and Mithya Ahara (Irregular Diet) aggravate or vitiate the Dosha (especially Vata). Other Aharaj Nidana which leads to Manda Agni are responsible for aggravation of disease. No disease can be originated without vitiation of Agni. ${ }^{3}$ In modern era spicy, oily, salty, junk, preservative food is very common, are the root cause of Mukhdushika.

Vihara: - Viharaja Hetu also play an important role in the production of Mukhdushika like Ratri Jagran, Shok, Chinta, Krodh, Divaswapan. In modern lifestyle stress, hormonal disturbances (due to different factors like puberty etc.), use of different types of cosmetics, drugs or medications etc. 


\section{Samprapti}

Ayurvedic view: In classics, there is no separate description regarding the Samprapti of Mukhdushika. But being a variety of Kshudra roga the common Samprapti of Kushtha should be considered. According to Sushruta Samprapti of Kshudra is as follows. The various causative factors are mentioned in Kshudra Nidana in which Vata and Kapha Doshas are mentioned.

- Dosha - Vata, Kapha

- Dushyas - Twak, Rakta, Mansa

- Srotas - Rasavaha, Raktavaha, Mansavaha, Medovaha

- Srotodusti-Sanga

- Udhbhavasthana - Twak, Mansa

- Purvarupa-Kandu, Shotha, Vedna

- Rupa-Pidika (similar to Shalmali Kantaka), Ruja, Kandu, Strava)

- Agni - Mandagni

Modern view: Acne is chronic inflammatory disease of the pilosebaceous glands present in the skin of the face. This disease is characterised by the formation of comedowns [blackheads], erythematous papules and in a few cases, nodules or cyst and scarring. There are four major factors involved in the disease production viz, increased sebum production, cornification of pilosebaceous ducts, microbial involvement and production of inflammation.

Action of Drug \& Other Procedure in Management of Vicharchika

- Kaishor guggulu4- Raktshodhak, kushthghan, Vrnya

- Kanchar guggulu ${ }^{4}$ - kushthhar, kushthghan, Vrnya, Shothahar

- Rasmanikya ${ }^{5}$ - Vata-Kaphdoshar

- Gandahk Rasayana ${ }^{6}$ - Raktashodhak, Kandughana, Rasayana.

- Godanti Bhasam ${ }^{7}$ - Pitta Shamak, Vednahara
- Manjistha ${ }^{8}$ - Varnya, Shothahara, Kushtaghana, Raktaprasadana, Rasayana, Shonitasthapan.

- Neem ${ }^{8}$-Kapha-Pittahara, Kandughna, Rakta Shodhaka, Vrana Shodhana, Putihara.

- Shunthi ${ }^{8}$-Vata-Kaphashamak, Deepan, Pachan, Shoolprashmana, Aampachak

- Haritaki $^{8}$ - Tridoshahar, Shonitsthapan, Shothahar, Vednahar, Deepana, Pachana

- Chitrak $^{8}$ - Vata-kaphashamak, krimighan, Deepan, Pachan, Shothahar

- Pippali ${ }^{8}$-Vata-kaphashamak, Deepan, Vatanulomana

- Kutaj Twak ${ }^{8}$ - Kapha-Pittahara, Kandughna, Rakta Shodhaka, Krimihara, Aam Nissaraka.

- Bilva Gooda $\boldsymbol{8}^{8}$ - Vata-kaphashamak, Shothahar, Deepan, Pachan, Grahi,

- Jalaukavacarana - Jalaukavacarana being a biopurificatory method removes deeply seated toxins by letting out blood, clearing Srotasa and pacifying vitiated Dosha.

\section{Aahar And Vihar Advised During Treatment}

$>$ Pathya-Green grams, rice, wheat, green vegetables, fruits (mostly red), Adequate sleep at night. Daily minimum 10-15minutes of Pranayam in fresh Air. Washing face every time after coming from outside environment and while sleeping.

$>$ Apathya- Oily, fried, spicy eatables, bakery items, curd, junk food, cold drinks etc. Ratreejagran, $\mathrm{Di}$ waswap, squeezing of acne.

\section{Result}

The results observed after treatment - Improvement in sign and symptoms of the patient, 5-6 days after the treatment started. Significant relief was found in Daha (burning sensation), Shoth(inflammation) and no new acne formed, upto the second visit (14th day). Satisfactory/rapid/dramatic improvement in Kandu (itching), Daha (burning sensation), Vaivranyata (discoloration) etc, at end of $7^{\text {th }}$ week. 

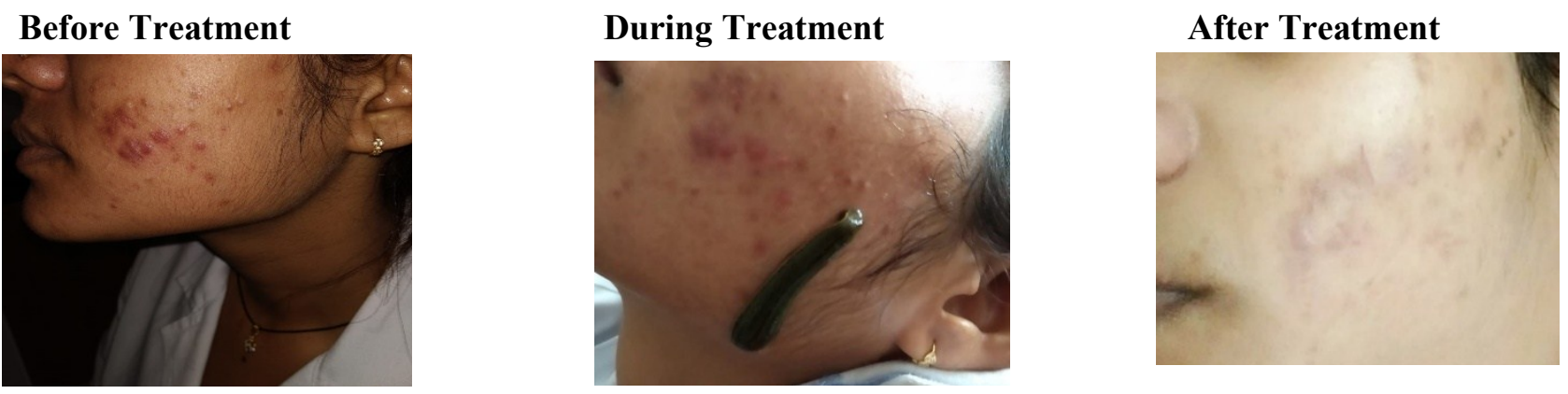

\section{DISCUSSION}

Day by day, embellishments are increasing in a common man's lifestyle. People are becoming more conscious of their beauty and skin. Still, modern medical science is not able to provide a permanent and economical solution for skin disorders especially acne. In Ayurveda texts Acharya Susruta has described the Pidika like Salmali-Kantaka and Vata, Kapha and Rakta as the chief culprit Dosha responsible for the disease, although Raktaja/Pittaja symptoms are found to be more pronounced in the patients. As Pidika is the chief complaint found in the patients, which is a Rakta Dushtilakșana. Acharya Vagbhatta has given a term Medogarbha pidika which can be assumed to be a lesion with whitish tinge or a lesion filled with Meda like substance i.e. sebum. On correlating this with modern description of acne lesion, this can be a closed comedone filled with sebum or a pustule. A Salmali-Kantaka like Pidika is suggestive of a lesion filled with Puya (pus) but in Apakvavastha (unripen), which shows involvement of Kapha. As Ayurveda advocates the use of Yukti (sense) in undescribed conditions, all these symptoms are obvious due to the involvement of vitiated Vata, Pitta and Kapha in the disease. Due to vitiation of Vata, pain, watery discharge and scar formation is possible while Pitta involvement can cause Paka. Vitiation of Kapha can lead to the formation of Puya, Sotha, Kleda/Snigdhata, Ghanasrava (thick discharge) and Kandu. All these symptoms correlate Mukhadusika with Acne vulgaris involving face only. In all KșudraRogas, Rakta-Dushti is seen as the prime pathology. While Raktamokșana is advocated as the preferred method of Sodhana or treatment in Rakta Dushti. As Mukhadusika is also a Kșudra-Roga, above statement is not an exception to it. While in many Kșudra Rogas,
Jalaukavacarana is directly indicated, Siravedha (venepucture) is mentioned as the preferred method of Raktamokșana in Mukhadusika. According to Acharya Susruta, Jalaukavacarana is the preferred method of bloodletting in Bala (children), Nari (female), Durbala (weak), Bhiru (fearful) and Sukumara (soft organs). As majority of our patients were going to be female which comes in Bhiru/Nari category, also the major age group in which this disease occurs belongs to Sukumara category, Jalaukavacarana was selected as the primary intervention. Jalauka is also said to be the best Anusastra (used in place of sastra (surgical instrument) in those who fears from surgery by Acharya Vagbhatta. Also, the amount of oozed blood in case of leech therapy is very less in comparison to tradition venepuncture. Leech application not only removes blood from the site but also injects biologically active substances which help to manage various ailments. Like Hirudin and Calin, which act as anticoagulants, also preventing inflammation and slow cleansing of wound. It is already proven that leech saliva contains analgesics which may be the reason behind pain relief. It can also be assumed as the leech sucks stagnant blood resulting in the Sodhana of the morbid Dosha known as Srotosuddhi (cleansing of body channels) and trapped Vata gets relieved which was responsible for the pain. As Jalaukavacarana removes vitiated Pitta/Rakta, which causes reduction in Paka, Daha and number of pustules \& cysts. It also reduces the pooled blood and pus which results in Srotosodhana. This Srotosodhana causes normalization of Kapha and further reducing Kandu and no of comedones, papules \& nodules. As vitiated Pitta imparts different colours to the skin while Rakta causes improved complexion, relieving Vaivarnyata 
which might be the reason behind the reduced Vaivarnyata in the patients involved in this study. Manjistha, which acts directly on the Rakta Dhatu due to its Deepana property, it stimulates the Dhatvagni which results into the formation of superior quality of Rakta Dhatu. Due to the Kaphahara properties, it reduces the Vaktra Mukha Snigdhata in the patients. Due the Pittashamak properties of Manjistha, it can pacify the action of Pitta, which causes Daha. Because of Kapha, Pitta and Vatahara properties of Manjistha along with its Deepan action, it prevents the vitiation of Medagni resulting eruption of less no of Pidika. Manjistha has got Tikta Rasa and Usna Virya which helps in Dosa Pachana both in Kostha and Shakha. It also helps in the Dhatwagni Deepti (Suksma Pachana) there which results in the formation of good quality of Rakta Dhatu. So, we can consider that Manjistha, by the above mentioned properties, can break down the pathogenesis of the disease Yuvan Pidika and improve the diseased condition ${ }^{10}$.Gandhaka Rasayana is used in skin diseases and as a blood purifier, hence selected for study ${ }^{11}$.Pharmacologically drugs acts as Astringent Blood purifying agent antiseptic, analgesic, aromatic agent and useful in burning sensation, skin disease and blood impurities of the blood.

\section{CONCLUSION}

As per mentioned in Ayurvedic classics Mukhdushika is Kapha Raktaj Vyadhi. Jaloukavcharan is considered the main treatment in Rakta-Pradoshaj Vikara in day to day Ayurvedic practice. The result of the case study reveals that the Jaloukavcharan along with herbo-mineral drugs are found might be effective in treatment of Mukhdushika w.s.r. to acne vulgaris. This study reveals the potency and effectiveness of Ayuvedic medicines and procedures with evidence basis. It opens new door for more clinical study on Mukhdushika by the timetested holistic medicine system of Ayurveda.

\section{REFERENCES}

1. Susruta, Susruta Samhita. Ayurved Tatva Sandipika. Commentary, edited by Dr. Ambika Datta Shastri, Chaukhamba Sanskrit Publication, Varanasi, reprint 2005; Nidanasthana, 13(39).
2. Vagbhatta, Astanga Hṛdaya, Sarvangasundara of Arundatta and Ayurvedarasayana of Hemadri, edited by Pt. Hari Sadashiva Shastri Paradakara Bhisagacharya, Chaukhamba Surbharati Prakashana, Varanasi, reprint 2007; Uttara tantra, 31(5):888

3. Vagbhatta, Astanga Hrudaya, Sarvangasundara of Arundatta and Ayurvedarasayana of Hemadri, edited by Pt. Hari Sadashiva Shastri Paradakara Bhisagacharya, Chaukhamba Surbharati Prakashana, Varanasi, Chaukhamba Sanskrit Sansthan, Varanasi, Reprint 2018; Sutrasthana, 15(134), NidanaSthana 12(1):513

4. Sharangdhar, sharanghdhar Samhita, Tatavdipika Hindi Commentary - Pd Durgadatt Shastri Choukhamba Sanskrit Prathisthan, Varanasi, Reprint 2002, Madhyam Khand 7(70-81):381, (97-102):385

5. Bhatt Krishanaram, Manimala Siddha Bheshaja, kaladhar Bhatt Hindi Commentary, Choukhamba Orientallia, Varanasi, reprient 1998, vol 1:48-49

6. Laxmipathi Shastri Rasayanadhikara, Yogaratnakara, Chaukhamba Sanskrit Sanstha Publication,Varanasi, reprint 1983, (1-4):501

7. Sadananda Sharma, Rastarangini, Motilal Banarsidas Publisher, New Delhi, 11 editions, 1982, 11(241):284

8. Prof. P.V. Sharma, Dravyaguna Vigyana, Chaukhamba Bharti Academy, Varanasi, Vol-II, Reprint 2012; 800801, 149-150, 331-335, 752- 753, 359-360, 275-277, 463-465, 455-457.

9. Susruta, Susruta Samhita. Nibandha Sangraha commentary of Shri Dalhanacharya Vaidya Yadavaji Trikamaji Acharya, Reprint Chaukhamba Sanskrit sansthan, Varanasi, Reprint 2019 Sutrasthana, 13(3).

10. An Aetiopathological Study of Yuvan Pidaka W. S. R. To Rakta And Shukra Dushti And Therapeutic Trial of Respective Shodhak Drugs, Research Article by Baishya Mrinal, International Ayurvedic Medical Journal, ISSN:2320 5091 IAMJ: Volume 1; Issue 3; May June 2013

11. Management of Acne Vulguris by Principles of Ayurveda: a case study, Pradip kinage etc, March-April 2016, DOI: $10.7897 / 2277-4343.07284$

\section{Source of Support: Nil \\ Conflict of Interest: None Declared}

How to cite this URL: Punita Sharma et al: To Evaluate The Effect Of Jalaukavcharana In Management Of Mukhdushika W.S.R To Acne Vulgaris: A Case Study. International Ayurvedic Medical Journal \{online\} 2020 \{cited May, 2020\} Available from: http://www.iamj.in/posts/images/upload/2357_2362.pdf 